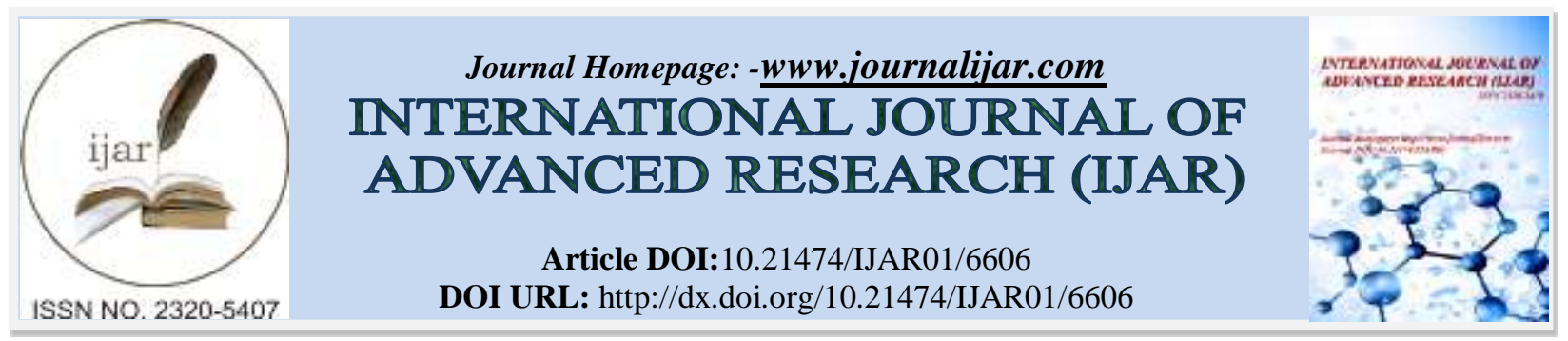

RESEARCH ARTICLE

\title{
LEARNING BASED VALUE OF CHARACTER IN EFFORTS LOCAL CULTURAL AND DEVELOPMENT MELAYU-LANGKAT.
}

\author{
Muhammad arif hidayat. \\ Lecturer STAI Jam'iyah Mahmudiyah and Lecturer of Medan State University.
}

\section{Manuscript Info}

Manuscript History

Received: 22 December 2017

Final Accepted: 24 January 2018

Published: February 2018

Keywords:-

Learning, values, local

wisdom, culture,Malay-Langkat

\section{Abstract}

This research is motivated by the facts and demands that the learning of Islamic Religious Education is actually loaded with character values in accordance with the demands of the characteristic curriculum in 2013. The fact to develop values and characters is not easy. Especially should emphasize the need for local wisdom of Malay Langkat culture in accordance with Islamic Religious concepts. To answer the problem, then do research in Madrasah Aliyah Se-Town Tanjung Pura with respondents as much as 6 teachers PAI. While the population of 1011 people and samples taken by $35 \%$ (354 students). Sampling is based on the national exam passing grade of the school (high, medium and low ranking school category). Data collection through questionnaire, observation and interview with descriptive analysis technique. The results of data analysis showed the overall score of each indicator is known to be on score: $77.404 \%$ which means that the development of the character value has been done in good category. Similarly, the student's statement on the teacher's efforts in implementing the character's values on culture is at a good level, shown by the score: $71,66 \%$.

Copy Right, IJAR, 2018,. All rights reserved.

\section{Introduction:-}

As an effort to form the nation's personality, education must refer to the people's expectation toward the realization of national aspiration as envisaged in Law no. 20/2003 on the National Education System that the objectives of national education are: "... for the development of the potential of learners to become human beings who believe and fear Allah Almighty, have noble character, healthy, knowledgeable, capable, creative, independent" National Education System Act (UU SISDIKNAS, 2003: 17).

The necessity of a man of noble character shows that the development of education in accordance with his nature both as a creature of God and social beings. The establishment of quality human resources of Indonesia there is no real reason of our constitution where the character of the nation is one that is desired in the development process ". Therefore it should be that in the formulation of national educational goals have been formulated how character education is included into it.

The guidance of the principle of noble in the development of competence of learners is the right choice that must be supported by all parties. These character values are fundamental foundation in human resource development. By 
adhering to the principle of faith and piety and noble morals then education as an effort to realize the nation's generation will produce quality human resources and intact.

It is realized that to realize a balanced learning atmosphere of values and attitudes is not easy because learning during this time is still dominated by the development of material knowledge, less attention to aspects of values and attitudes. Educational backgrounds in colleges that further develop cognitive abilities are also very influential in shaping the ability and personal teachers.

Naturally, if a number of studies find facts with less favorable conditions. Generally PAI teachers in developing learning objectives do not begin with an analysis of the characteristics of students, so that information about what should be taught to students becomes incomplete. This results in less meaningful content and learning quality. Kusnadi (2000: 7), in his research found the gap, among others: pragmatic material presentation; without comprehension of formal object comprehensively by considering aspects of relation and interrelation between character phenomena. Thus the type of performance and learning targets are concerned with cognitive material. While the evaluation is done partially on the material knowledge (cognition). Whereas in KBK curriculum affirmed that the base of competence must guarantee the growth of faith and devotion to God Almighty, the mastery of life skill, academic, and art, development of strong Indonesian personality and morality (Depdiknas 2000: 6).

In this connection it is necessary to improve the quality and quality of education in accordance with the needs of learners. This is where reorientation of appropriate learning strategies and methodologies is required, enriching teachers' knowledge and skills in designing appropriate learning models and strategies. In the end the teacher can improve his ability in instilling religious insight related to psychological elements (faith, taste and ratio). Teachers can present the material of PAI as a whole both in the physical and social sense of religion.

Implementation of PAI education is required to be able to develop aspects of values and attitudes in Java in the social context. Such efforts in addition to the strong will also need the existence of the design of learning in accordance with the type of content and learning objectives. For that we need a model of learning and design value and character. The problem is how to model the appropriate learning design for PAI learning based on character values and how efforts that have been done along with the enactment of characteristic curriculum.

\section{Platform Theory:-}

The definition of value according to Fraenkel (1989: 23) is "... is an idea a concept-about what some one thinks is important in. When a person values something, He or She deems it worthwhile having, worth doing, or worth trying to obtain. "Values are said to be of the utmost importance to human life.The value serves as a reference for a person in acting and acting Djahiri (1996: 6) defines:" Values are a provision of what is good, righteous, just and beautiful. Values are a standard for considering and educating what behaviors are appropriate and inappropriate or unfavorable."

Islamic Religious Education both taught in school and college can not be separated from the content of values. The value of existence is identical and can not be separated from the material of character education and morals both in scientific value, philosophy and deity. Arifin (1996: 17) says:

Each field of science, including the Islamic Religious Education, has value, both for itself and for other sciences, or even for life in general. As a teaching field, PAI is loaded with philosophical, as well as scientific values. Through the process of education, in the end man will realize the value of his relationship with God Maker.

By understanding the values in the education of PAI then obtained the benefits of knowledge as well as aspects of values and attitudes. In this connection Arifin (1996: 17) said: By studying PAI man will realize the value of his relationship with God the Creator. Here the PAI not only presents itself as a science that has philosophical value, but also has a divine value that connects people with their Lord.

The definition of character literally means mental qualities or moral strength, morality or character of the individual who becomes the special personality, the driving and activator, and the differentiator of one individual with another (Koesoema, 2011: 41). Meanwhile, according to Samani (2011: 43) character is a way of thinking and behave that are typical of each individual to live and work together, both within the family, society, nation, and country. Thus character education is a system of applying moral values to learners through educational activities. 
The term character education is also affirmed Zubaedi (2011: 26), among others:

Character education is an effort to cultivate intelligence in thinking, appreciation in the form of attitude, and practice in the form of behavior in accordance with the noble value that becomes his identity, manifested in the interaction with God, self, between, and the environment. These noble values include honesty, independence, courtesy, social glory, thinking intelligence including intellectual cultivation, and logical thinking. Education has several main objectives namely; developing the potential of soul / conscience / affective learners as human as well as citizens of the nation; develop the habits and behaviors of learners who are praiseworthy, inculcate the soul of leadership and responsibility, develop learners become independent, creative, and nationalized, develop a safe, honest, creativity and friendship learning environment.

In the vision of the application of character education, it is necessary hard work of all parties, especially on programs that have a major contribution to the nation's civilization must be optimized. Therefore, the application of character education requires an understanding of the concepts, theories, methodologies and applications relevant to character building and character education.

Character education has been the concern of many countries in order to prepare quality generations, not just for the individual interests of the citizens, but also for the people as a whole.

In the Regulation of the Minister of National Education No. 23 of 2006 affirmed:

That the purpose of character education in schools is intended to facilitate learners to develop the characters especially those covered in graduates of the Competency Standards of Graduates. so they become a person of noble personality (smart and competitive). While the target of character education in schools is intended to facilitate learners to develop characters especially those covered in graduates of Competency Standards Graduates so that they become beings of noble personality (smart and competitive). Universally various characters are defined as the value of coexistence based on the pillars; peace, respect, cooperation, freedom, happiness, honesty, humility, love, responsibility, simplicity, (simplicity), tolerance (tolerance) and unity (unity) (Kemendiknas RI, 2010: 37).

Type of character value found there are religious and moral character. The religious character is applied in the form of a good behavior life; full of virtue; ie to behave well toward the other (God Almighty, human, and universe) and to self. Moral character according to Dewantara, is to support the development of the child's life, the birth and the mind from nature to the direction of a civilization. Here it is clear that moral education essence is to develop moral intelligence (building moral intelligence) or develop the moral ability of children, so as to determine right and wrong, good and bad, reasonable and unnatural, appropriate or inappropriate, and inappropriate or inappropriate to work on someone (Dewantara, 1962: 25).

Still according to Dewantara (1962: 26) that the target character education is all schools in Indonesia public and private in various levels of education. All school residents, including students, teachers, administrative staff, and school leaders are targeted by the program. Schools that have been successful in carrying out character education as well as best practices, which became an example to be disseminated to other schools. Through this program is expected to graduate school has faith and devotion to God Almighty, noble character, noble character, full and integrated academic competence, as well as having a good personality according to the norms and culture of Indonesia.

\section{Research Methods:-}

This research was conducted at Madrasah Aliyah in Tanjung Pura. Based on the ranking of national exam results have variations ranging from the category of most quality schools, moderate and less. At the MA level because of the entire PAI materials taught in schooling turned out in class $\mathrm{X}$ is considered the most loaded with the content of values and characters that must be developed.

\section{Research Approach:-}

The approach of this research is the implementation of educational model characterized by using Qualitative Research procedure. In accordance with its purpose, this research intends to know conceptual and implementation model about character model learning. 


\section{Population And Sample Research:-}

This research is focused on Madrasah Aliyah in Tanjung Pura Regency. Langkat with the respondents teachers and students. For samples from this research students only take students of class X Religion, for the sample of teachers directly taken from teachers of study areas Aqidah Akhlak teaching in Madrasah Aliyah Tanjung Pura. While for the sample of students based on the total number of students in four schools with a total of 1011 people and samples taken as much as $35 \%$ or as many students.

\section{Data Collection Techniques:-}

To collect the data used the technique First, the questionnaire is to capture the teacher data about learning PAIAqidah Akhlak which is charged value, both the relegius value and the value in accordance with the local cultural values system such as Malay Langkat cultural values. Questionnaires are also used to students to capture the data whether the learning PAI Aqidah Akhlak they learn to load the values of characters that are identical with the phenomenon of character and morals that is Langkat Malay Culture.

Second observation, this technique is intended to collect data directly related to the teacher's work ability, response and student attitude that is seen in the process of learning in the classroom. This is necessary in the effort to improve the draft of PAI Aqidah Akhlak learning model that is being developed by including value contents in accordance with the cultural value system owned by the community. The third documentation, intended to obtain data about the general picture or profile of each school. The documentation is also intended to collect data on the learning implementation plan (RPP) needed to see how the planning done by the teachers of Akidah Akhlak.

\section{Data Analysis Technique:-}

Corresponding In accordance with the nature and purpose of this study is to produce an informsi and concepts of cultural values in learning PAI Akidah Akhlak then the data collected in this development include data: design of learning, pelaksaanaan, and evaluation of learning character as a form of local cultural wisdom Melayu Langkat.

\section{Results And Discussion:-}

\section{Development of Malay Character and Cultural Values of Langkat}

Implementation of character education as a form of local wisdom of Malay Langkat culture in the subjects of Akidah Akhlak in MA Negeri 1, MA Negeri 2, Private MA Jam'iyah Mahmudiyah Tanjung Pura A total of 506 students Students are explained through three variables, including: planning, implementation and evaluation.

To find out whether the teacher is guided by the learning plan of character and Malay culture can be seen in the following Table 1 below.

Table 1:- Teacher of Akidah Akhlak Teaching Based on RPP

\begin{tabular}{|c|c|c|c|}
\hline Number & Categorized & Quantity & Percentage \\
\hline 1 & Always & 6 & $100 \%$ \\
\hline 2 & Often & 0 & $0 \%$ \\
\hline 3 & Sometimes & 0 & $0 \%$ \\
\hline 4 & Never & 0 & $0 \%$ \\
\hline
\end{tabular}

Based on the above table it can be concluded that teachers of Akidah Akhlak always make preparations before teaching. This means that in terms of planning they already have a learning program according to the applied curriculum. Furthermore, how the implementation that describes the implementation of the character value can be seen in the following Table 2.

Table 2:- Teacher of Akidah Ethic Enter Character Value And Formulate In SK And KD Learning

\begin{tabular}{|c|c|c|c|}
\hline Number & Categorized & Quantity & Percentage \\
\hline 1 & Always & 3 & $50 \%$ \\
\hline 2 & Often & 2 & $33.3 \%$ \\
\hline 3 & Sometimes & 1 & $16.7 \%$ \\
\hline 4 & Never & 0 & $0 \%$ \\
\hline
\end{tabular}


Based on the data above table it is known that the teacher of Akidah Akhlak has linked the learning model of Akidah Akhlak with the values of characters in accordance with the Malay cultural values system this can be seen from the teacher's answer for the effort to include the value of character and cultural value value with a percentage of $83.3 \%$ which very often associate the values of these characters, as for the values of the character that is reflected is the attitude of self-discipline on duty and commitment, the value of this discipline in Malay terms similar to that of Tenas Efendi (2005: 49), as follows: "Attitude of life holding the mandate, the faithfulness of holding the mandate, firmly upholding the oath, steadfast hold of the promise, diligently perform the duties of duty and obey the law ". The character values illustrated by the teacher's behavior can not be denied that the role of the teacher as the leader who protects the "people" in this case is the learner, and the teacher must be able to set an example to all the students he teaches. Knowing the assertion about whether the teacher opens learning by praying can be traced as follows in Table 3 below.

Table 3:- Teacher of Akidah Akhlak Opening the Process of Teaching and Learning by Reading Prayer

\begin{tabular}{|c|c|c|c|}
\hline Number & Categorized & Quantity & Percentage \\
\hline 1 & Always & 2 & $33.3 \%$ \\
\hline 2 & Often & 2 & $33.3 \%$ \\
\hline 3 & Sometimes & 1 & $16.7 \%$ \\
\hline 34 & Never & 1 & $16.7 \%$ \\
\hline
\end{tabular}

From the table above it is known that the geography teacher has done adab that beradat by starting learning by reading the prayer or guiding and directing to students to always pray in every start work, this is very in accordance with the values of Melayu attached to Allah SWT, as which is expressed by Tenas Efendi (2005: 50), that man must have a realizing nature as a servant of Allah, because with that consciousness that will encourage man to become taqwa and make himself useful for all creatures of God and responsible for the preservation of nature creation Allah .The teacher's effort included the value of the character and the value of the cultural value with the category percentage very often $33.30 \%$ + the category often with the amount of $33.30 \%$, bringing the total as a whole of $66.30 \%$. This indicates that the teacher has given a model example, in Langkat Malay society this is very important, because adab learn in Malay cultural value stated by Tenas Efendi (2011: 70) as follows:

"Demanding knowledge should be solemn, To Allah pleading guidance, in order to get a beautiful science". "To demand the knowledge of righteousness, to Allah to ask for mercy, so that knowledge brings benefits, prosperous life of the hereafter."

The passage of the meaning of the Malay cultural value system above shows that as a person who is gathered in an existing place / organization and environment, must always feel what is felt by others let alone learners which is the closest part of the school component, therefore it is something that right and have the rightness and even should be done by the teacher and always direct students to pray for each other for the good. Praying is the base of all good works.

The passage of the meaning of the Malay cultural value system above shows that in doing verbal interaction (language), it should be done with a commendable, civilized, polite communication and considering the psychological side of the person who is spoken to, let alone in the capacity to admonish for the performance of students who are not in accordance with school rules. Teachers must also adapt to the meaning and purpose clearly in accordance with the norms and culture of the local community.

Although there are $16.7 \%$ who responded with a 3rd alternative that sometimes just put the value of this character is more due to not accustomed to emphasize aspects of character values in learning as expressed by teacher $\mathrm{Hj}$ Usmaidar, M.Pd. (October 5, 2014) stating that:

"Karna is still in the 2006 curriculum (KTSP) the value of characters in learning is not a major emphasis, therefore sometimes we are more focused in achieving the target subject matter that has been set".

Therefore, this should be the attention of the school (principal) in order to improve teacher qualifications, especially for the demands of the curriculum 2013. On the other hand teachers of Akidah Akhlak should always be creative and innovative inherit the values of characters that can be inherited to learners, because these values can help students be more able to survive in their lives for the present and future. The teacher's effort to include the value of 
the character and the value of the cultural value thus has a high percentage of values, the values that need to be considered and maintained the same as the values contained in the previous. Malay culture strongly encourages the learning process of mutual respect in the effort to accelerate the achievement of learning objectives so that students can have local wisdom of Malay culture Langkat is upheld into Table 4.

Table 4:- Teacher of Akidah Akhlak Directing Interaction of Inter-Student Education With School Environment And Environment Around Student Residence

\begin{tabular}{|c|c|c|c|}
\hline Number & Categorized & Quantity & Percentage \\
\hline 1 & Always & 2 & $33.3 \%$ \\
\hline 2 & Often & 2 & $33.3 \%$ \\
\hline 3 & Sometimes & 1 & $16.7 \%$ \\
\hline 4 & Never & 1 & $16.7 \%$ \\
\hline & Total & $\mathbf{6}$ & $\mathbf{1 0 0} \%$ \\
\hline
\end{tabular}

Based on the data from the table above the teacher teaches students to do a good educational interaction with the learning environment that is certainly associated with the assignment to students related to the Akidah of Morals is to maintain nature and the environment. The teacher's effort included the value of character and the value of cultural values in the educational interaction with the environment in accordance with the value of the melayu Tenas Efendi (2010: 208), as follows:

"The so-called adat in the kampung, the custom is maintained by the institution upheld, the house is set in a hamlet confined, the broad yard of the field, the suak and the river are equally protected, the forest is kept alive, there where the grandchildren take refuge".

The learning process relating to the environment teaches students that learning resources can be universes (environment / field), can also be in a laboratory or museum, the values contained in these conditions show that, as introduced in Malay culture: "nature ta kambang being a teacher ". Another language in Islam is known as kauniyah verses ". Meanwhile, in the Malay Culture system, the interaction of education in the Teaching and Learning Process in accordance with the value of Melayu Tenas Efendi (2010: 37), as follows: "If you sit down, you can not ask" ... "revealed by the door of his knowledge wide-spread nature ".

Excerpts of values contained in the above Malay cultural values is more on the affirmation that learning should indeed seek knowledge that brings benefits to the student's self is also beneficial for others and the environment. The claimant of science must be assisted, so that the road is not deadlocked, the claimant of science must be defended so that business is not constrained, the claimant of science must be helped to walk to the end, the claimant of knowledge must be considered so as not broken in the middle of the road. "To the claimant of knowledge appears interested, reprimanded greeted by encouragement, so that his steps are not rushed and knowledge is required to bring benefits" (Tenas Efendi, 2011: 47).

Petukan meaning of the above statement is as a student must have a strong soul never give up and patience for what is directed by the teacher in order to create personal learners. Personal learners are very useful for a better life. In this case in accordance with the value of Melayu dikenkan Tenas Efendi (2011: 247), as follows:

"When life is self-confident the spirit of awakening marwah stand" ... "If you want to establish marwah, selfconfidence do not change, the spirit rose up heart was steadfast, facing challenges are not wobbly, life is dead livable".

Excerpts of the meaning of the above statement is with confidence that formed by the learning process is done by asking students dare to explain what is in their tasks will be able to build a very good personality in building a nation and self marwah. as a student must have a strong and resilient soul and tough on every challenge in the form of questions and persilang opinions in the discussion. Personal learners like that which is expected a society is very useful for a better life in the future. Therefore this should be the attention of both teachers and students because it is in accordance with the spirit of Malay culture.

In this case in accordance with the value of Melayu Tenas Efendi (2011: 247), as follows: "If you want to build a nation, abstinence despair" on the other hand there is also the Malay cultural values associated with the attitude that does not give up and try to solve problems , as in Tenas Efendi (2005: 55), as follows: 
"Arif listened to the magpie, wisely dismissing the wind, wisely heard the leaves of the leaves, wise see the stars in the sky, wise to see people's wisdom, wisely dismissed the sword's eyes, wisely open the knot of death, clever mengimpung with tongue, clever menggadang with ably, syarak, clever with the customs binding with the institution $"$.

Clarify the meaning of the above statement is a human figure needed in the community is a person full of wisdom in the face of various problems and trials, have a wise attitude, responsive and dexterous so as to make the right decision and useful. The passage of the relevant Malay cultural values states that anyone with his profession or his work is moreover the teacher must be able to carry out his duties as well as possible, making the work agenda as it should be, because the teacher also works on his oath of office.

Overall description of character value development based on local Langkat Malay cultural wisdom can be seen in the following Table 5 below.

Tabel 5:- Educational Planning Character Subjects Akidah Akhlak

\begin{tabular}{|c|c|c|c|c|c|c|c|c|c|c|}
\hline No & A & $\%$ & B & $\%$ & C & $\%$ & D & $\%$ & \multicolumn{2}{|c|}{ Total } \\
\hline 1 & 3 & 50 & 2 & 33.3 & 1 & 16.7 & 0 & 0 & 6 & 100 \\
\hline 2 & 3 & 50 & 2 & 33.3 & 1 & 16.7 & 0 & 0 & 6 & 100 \\
\hline 3 & 2 & 33.3 & 2 & 33.3 & 1 & 16.7 & 1 & 16.7 & 6 & 100 \\
\hline 4 & 2 & 33.3 & 2 & 33.3 & 1 & 16.7 & 1 & 16.7 & 6 & 100 \\
\hline 5 & 3 & 50 & 2 & 33.3 & 1 & 16.7 & 0 & 0 & 6 & 100 \\
\hline 6 & 3 & 50 & 2 & 33.3 & 1 & 16.7 & 0 & 0 & 6 & 100 \\
\hline 7 & 3 & 50 & 2 & 33.3 & 1 & 16.7 & 0 & 0 & 6 & 100 \\
\hline 8 & 4 & 66.7 & 2 & 33.3 & 0 & 0 & 0 & 0 & 6 & 100 \\
\hline 9 & 4 & 66.7 & 2 & 33.3 & 0 & 0 & 0 & 0 & 6 & 100 \\
\hline 10 & 4 & 66.7 & 2 & 33.3 & 0 & 0 & 0 & 0 & 6 & 100 \\
\hline 11 & 4 & 66.7 & 2 & 33.3 & 0 & 0 & 0 & 0 & 6 & 100 \\
\hline 12 & 2 & 33.3 & 2 & 33.3 & 1 & 16.7 & 1 & 16.7 & 6 & 100 \\
\hline 13 & 2 & 33.3 & 2 & 33.3 & 1 & 16.7 & 1 & 16.7 & 6 & 100 \\
\hline 14 & 2 & 33.3 & 2 & 33.3 & 1 & 16.7 & 1 & 16.7 & 6 & 100 \\
\hline 15 & 2 & 33.3 & 2 & 33.3 & 1 & 16.7 & 1 & 16.7 & 6 & 100 \\
\hline 16 & 2 & 33.3 & 2 & 33.3 & 1 & 16.7 & 1 & 16.7 & 6 & 100 \\
\hline 17 & 3 & 50 & 2 & 33.3 & 1 & 16.7 & 0 & 0 & 6 & 100 \\
\hline 18 & 3 & 50 & 2 & 33.3 & 1 & 16.7 & 0 & 0 & 6 & 100 \\
\hline 19 & 2 & 33.3 & 2 & 33.3 & 1 & 16.7 & 1 & 16.7 & 6 & 100 \\
\hline 20 & 2 & 33.3 & 2 & 33.3 & 1 & 16.7 & 1 & 16.7 & 6 & 100 \\
\hline 21 & 2 & 33.3 & 2 & 33.3 & 1 & 16.7 & 1 & 16.7 & 6 & 100 \\
\hline 22 & 2 & 33.3 & 2 & 33.3 & 1 & 16.7 & 1 & 16.7 & 6 & 100 \\
\hline 23 & 2 & 33.3 & 2 & 33.3 & 1 & 16.7 & 1 & 16.7 & 6 & 100 \\
\hline 24 & 2 & 33.3 & 2 & 33.3 & 1 & 16.7 & 1 & 16.7 & 6 & 100 \\
\hline 25 & 2 & 33.3 & 2 & 33.3 & 1 & 16.7 & 1 & 16.7 & 6 & 100 \\
\hline 26 & 2 & 33.3 & 2 & 33.3 & 1 & 16.7 & 1 & 16.7 & 6 & 100 \\
\hline Total & $\mathbf{6 7}$ & & $\mathbf{5 2}$ & & $\mathbf{2 2}$ & & $\mathbf{1 5}$ & & - & - \\
\hline & & & & & & & & &
\end{tabular}

The table above illustrates the options (a) of 67 answers, options (b) of 52 respondents, 22 (c) option as many as 22 respondents, option (d) of 15 respondents. Furthermore, to obtain the total value of the data presented, the total number of respondents who choose each option will be multiplied by the predefined score standard in each of the answer options contained in the questionnaire. The calculation is performed as follows: 
Table 6:- Number of Answers to Alternative Answers Answer

\begin{tabular}{|c|c|c|c|}
\hline \multicolumn{2}{|c|}{ Answer option } & Score & Total \\
\hline A (4) & 67 & $67 \times 4$ & 268 \\
\hline B (3) & 52 & $52 \times 3$ & 156 \\
\hline $\mathrm{C}(2)$ & 22 & $22 \times 2$ & 44 \\
\hline $\mathrm{D}(1)$ & 15 & $15 \times 1$ & 15 \\
\hline & \multicolumn{2}{|c|}{ Score F } & 483 \\
\hline
\end{tabular}

Thus, the value of $\mathrm{F}$ can be determined from the data processing that is 483 While the value of $\mathrm{N}$ can be determined by summing the respondents who chose the options A, B, C, D and E namely: $67+52+22+15=156$ Furthermore used the formula calculation percentage for determine how the planning of character education and Malay culture in the subjects of Akidah Akhlak in MAN 1 Tanjung Pura, MAN 2 Tanjung Pura and MA Private Jam'iyah Mahmudiyah in Tanjung Pura, Langkat which can be known in percentage form as follows:

$$
\begin{gathered}
p=f / n \times 100 \% \\
p=483 /(156) \times 100 \%
\end{gathered}
$$

Then P: 309, 6154\%: 4 Option: 77, $40385 \%$

By seeing and consulting the standard percentage determined to measure the character education planning of Malay culture on subjects of Akidah Akhlak in MAN 1 Tanjung Pura, MAN 2 Tanjung Pura and Private MA Jam'iyah Mahmudiyah in Tanjung Pura is known to be at a good level, indicated by Score: $77.404 \%$.

In order for more valid data required checks and rechecks through Trianggulasi Data from student statements, data from students is only used for proof of how teachers implement learning that is characterized by the value of characters in accordance with the system of cultural values. The presentation of data will not be analyzed because in the analysis it only requires the questionnaire recapitulation value to be analyzed with the percentage ranges previously defined in Chapter III in the methodology.

The students who become respondents are the students of class X in MAN 1 Tanjung Pura, MAN 2 Tanjung Pura and Private MA Jam'iyah Mahmudiyah in Tanjung Pura. Tracking data through 26 indicators overall can be displayed in the following table recap into Table 7 below.

Table 7:- Recapitulation of Student Statement on Implementation of Islamic Character Learning on Character Values

\begin{tabular}{|c|c|c|c|c|c|c|c|c|c|c|}
\hline Number & $\mathrm{A}$ & $\%$ & $\mathrm{~B}$ & $\%$ & $\mathrm{C}$ & $\%$ & $\mathrm{D}$ & $\%$ & \multicolumn{2}{|c|}{ Total } \\
\hline 1 & 76 & 13.69 & 357 & 64.32 & 122 & 21.98 & 0 & 0.00 & 555 & 100 \\
\hline 2 & 86 & 15.50 & 335 & 60.36 & 129 & 23.24 & 5 & 0.90 & 555 & 100 \\
\hline 3 & 89 & 16.04 & 234 & 42.16 & 229 & 41.26 & 3 & 0.54 & 555 & 100 \\
\hline 4 & 72 & 12.97 & 362 & 65.23 & 120 & 21.62 & 1 & 0.18 & 555 & 100 \\
\hline 5 & 76 & 13.69 & 332 & 59.82 & 135 & 24.32 & 12 & 2.16 & 555 & 100 \\
\hline 6 & 79 & 14.23 & 343 & 61.80 & 108 & 19.46 & 25 & 4.50 & 555 & 100 \\
\hline 7 & 120 & 21.62 & 288 & 51.89 & 135 & 24.32 & 12 & 2.16 & 555 & 100 \\
\hline 8 & 76 & 13.69 & 357 & 64.32 & 119 & 21.44 & 3 & 0.54 & 555 & 100 \\
\hline 9 & 123 & 22.16 & 345 & 62.16 & 79 & 14.23 & 8 & 1.44 & 555 & 100 \\
\hline 10 & 143 & 25.77 & 289 & 52.07 & 102 & 18.38 & 21 & 3.78 & 555 & 100 \\
\hline 11 & 154 & 27.75 & 224 & 40.36 & 138 & 24.86 & 39 & 7.03 & 555 & 100 \\
\hline 12 & 167 & 30.09 & 243 & 43.78 & 141 & 25.41 & 4 & 0.72 & 555 & 100 \\
\hline 13 & 180 & 32.43 & 265 & 47.75 & 109 & 19.64 & 1 & 0.18 & 555 & 100 \\
\hline 14 & 179 & 32.25 & 255 & 45.95 & 120 & 21.62 & 1 & 0.18 & 555 & 100 \\
\hline 15 & 156 & 28.11 & 222 & 40.00 & 136 & 24.50 & 41 & 7.39 & 555 & 100 \\
\hline 16 & 133 & 23.96 & 128 & 23.06 & 222 & 40.00 & 72 & 12.97 & 555 & 100 \\
\hline 17 & 135 & 24.32 & 239 & 43.06 & 120 & 21.62 & 61 & 10.99 & 555 & 100 \\
\hline 18 & 133 & 23.96 & 128 & 23.06 & 222 & 40.00 & 72 & 12.97 & 555 & 100 \\
\hline
\end{tabular}




\begin{tabular}{|c|c|c|c|c|c|c|c|c|c|c|}
\hline 19 & 121 & 21.80 & 132 & 23.78 & 230 & 41.44 & 72 & 12.97 & 555 & 100 \\
\hline 20 & 127 & 22.88 & 243 & 43.78 & 113 & 20.36 & 72 & 12.97 & 555 & 100 \\
\hline 21 & 142 & 25.59 & 176 & 31.71 & 185 & 33.33 & 52 & 9.37 & 555 & 100 \\
\hline 22 & 154 & 27.75 & 220 & 39.64 & 138 & 24.86 & 43 & 7.75 & 555 & 100 \\
\hline 23 & 177 & 31.89 & 217 & 39.10 & 121 & 21.80 & 40 & 7.21 & 555 & 100 \\
\hline 24 & 133 & 23.96 & 262 & 47.21 & 118 & 21.26 & 42 & 7.57 & 555 & 100 \\
\hline 25 & 166 & 29.91 & 215 & 38.74 & 124 & 22.34 & 50 & 9.01 & 555 & 100 \\
\hline 26 & 122 & 21.98 & 238 & 42.88 & 165 & 29.73 & 30 & 5.41 & 555 & 100 \\
\hline Quantity & $\mathbf{3 3 1 9}$ & & $\mathbf{6 6 4 9}$ & & $\mathbf{3 6 8 0}$ & & $\mathbf{7 8 2}$ & & & \\
\hline Total & $\mathbf{1 3 2 7 6}$ & & $\mathbf{1 9 9 4 7}$ & & $\mathbf{7 3 6 0}$ & & $\mathbf{7 8 2}$ & & & \\
\hline
\end{tabular}

Thus, the value of $\mathrm{F}$ can be determined from the data processing that is 483 While the value of $\mathrm{N}$ can be determined by summing the respondents who chose the options A, B, C, D and E namely: $3319+6649+3680+782=14430$ Next use the formula calculation percentage for determine how the planning of character education and Malay culture in the subjects of Akidah Akhlak in MAN 1 Tanjung Pura, MAN 2 Tanjung Pura and Private MA Jam'iyah Mahmudiyah can be known in percentage form as follows:

$$
\begin{gathered}
p=\frac{f}{n} x 100 \% \\
p=\frac{41365}{14430}=268,6597: 4=71.66493 \%
\end{gathered}
$$

As stated in the table below, it is known that the result of the data from the top students in Table 1 to Table 8 implementation of Malay character and culture values in the learning of Akidah Akhlak class X in MAN 1 Tanjung Pura, MAN 2 Tanjung Pura and Private MA Jam'iyah Mahmudiyah is as follows :

$$
=\frac{41365}{14430}=268,6597: 4=71.66493 \%
$$

By looking at and consulting the standard percentage that is determined to measure the character education planning of Malay culture on subjects of Akidah Akhlak in MAN 1 Tanjung Pura, MAN 2 Tanjung Pura and Private MA Jam'iyah Mahmudiyah in Tanjung Pura is known by the students' statement on the teacher's efforts in implementing the character's top cultural values are at a good level, indicated by the score: $71,66493 \%$. While table 8 described recapitulation of data comparison from Master Akidah Ethic of Students.

Table 8:- Recapitulation of Data Comparison From Master of Akidah Ethic of Students

\begin{tabular}{|c|c|c|c|c|c|c|c|c|c|c|}
\hline \multirow{2}{*}{ Number } & \multicolumn{9}{|c|}{ Data From The Alternative Teacher's } & \multicolumn{5}{c|}{ Data From the MA Student Class X Alternative } \\
& \multicolumn{1}{|c|}{ A } & B & C & D & Total & A & B & C & D & Total \\
\hline & 3 & 2 & 1 & 0 & 6 & 76 & 357 & 122 & 0 & 555 \\
\hline 2 & 3 & 2 & 1 & 0 & 6 & 86 & 335 & 129 & 5 & 555 \\
\hline 3 & 2 & 2 & 1 & 1 & 6 & 89 & 234 & 229 & 3 & 555 \\
\hline 4 & 2 & 2 & 1 & 1 & 6 & 72 & 362 & 120 & 1 & 555 \\
\hline 5 & 3 & 2 & 1 & 0 & 6 & 76 & 332 & 135 & 12 & 555 \\
\hline 6 & 3 & 2 & 1 & 0 & 6 & 79 & 343 & 108 & 25 & 555 \\
\hline 7 & 3 & 2 & 1 & 0 & 6 & 120 & 288 & 135 & 12 & 555 \\
\hline 8 & 4 & 2 & 0 & 0 & 6 & 76 & 357 & 119 & 3 & 555 \\
\hline 9 & 4 & 2 & 0 & 0 & 6 & 123 & 345 & 79 & 8 & 555 \\
\hline 10 & 4 & 2 & 0 & 0 & 6 & 143 & 289 & 102 & 21 & 555 \\
\hline 11 & 4 & 2 & 0 & 0 & 6 & 154 & 224 & 138 & 39 & 555 \\
\hline 12 & 2 & 2 & 1 & 1 & 6 & 167 & 243 & 141 & 4 & 555 \\
\hline 13 & 2 & 2 & 1 & 1 & 6 & 180 & 265 & 109 & 1 & 555 \\
\hline 14 & 2 & 2 & 1 & 1 & 6 & 179 & 255 & 120 & 1 & 555 \\
\hline 15 & 2 & 2 & 1 & 1 & 6 & 156 & 222 & 136 & 41 & 555 \\
\hline
\end{tabular}




\begin{tabular}{|c|c|c|c|c|c|c|c|c|c|c|}
\hline 16 & 2 & 2 & 1 & 1 & 6 & 133 & 128 & 222 & 72 & 555 \\
\hline 17 & 3 & 2 & 1 & 0 & 6 & 135 & 239 & 120 & 61 & 555 \\
\hline 18 & 3 & 2 & 1 & 0 & 6 & 133 & 128 & 222 & 72 & 555 \\
\hline 19 & 2 & 2 & 1 & 1 & 6 & 121 & 132 & 230 & 72 & 555 \\
\hline 20 & 2 & 2 & 1 & 1 & 6 & 127 & 243 & 113 & 72 & 555 \\
\hline 21 & 2 & 2 & 1 & 1 & 6 & 142 & 176 & 185 & 52 & 555 \\
\hline 22 & 2 & 2 & 1 & 1 & 6 & 154 & 220 & 138 & 43 & 555 \\
\hline 23 & 2 & 2 & 1 & 1 & 6 & 177 & 217 & 121 & 40 & 555 \\
\hline 24 & 2 & 2 & 1 & 1 & 6 & 133 & 262 & 118 & 42 & 555 \\
\hline 25 & 2 & 2 & 1 & 1 & 6 & 166 & 215 & 124 & 50 & 555 \\
\hline 26 & 2 & 2 & 1 & 1 & 6 & 122 & 238 & 165 & 30 & 555 \\
\hline Total & $\mathbf{6 7}$ & $\mathbf{5 2}$ & $\mathbf{2 2}$ & $\mathbf{1 5}$ & $\mathbf{1 5 6}$ & $\mathbf{3 3 1 9}$ & $\mathbf{6 6 4 9}$ & $\mathbf{3 6 8 0}$ & $\mathbf{7 8 2}$ & $\mathbf{1 4 4 3 0}$ \\
\hline
\end{tabular}

\section{Conclusions And Suggestions:-}

\section{Conclusions:-}

Conceptually, the valuable learning design model and character on the subject of Akidah Akhlak is basically an educational program that organizes and simplifies the sources of moral values and is presented taking into account the social context of Malay Langkat culture.

Implementation of character education on the basis of Malay cultural values in the subjects Akidah Akhlak seen from the aspect of character education planning that includes: (1) Guru Akidah Akhlak based on School Activity Plan and Budget (RK-AS) character, (2) Guru Akidah Akhlak (3) teachers of Akhlak formulate RPP based on Malay character and culture (4) Guru Akidah Akhlak is guided by schedule of learning activity based on character and Malay culture, (5) Akidah Akhlak (teacher of morals) choosing and preparing Malay-based learning media and Malay culture, and (6) Guru Akidah Akhlak choose and prepare learning resource based on Malay character and culture.

The overall score of each indicator is known to be at a good level, indicated by the score: $77.404 \%$. Similarly, student's statement on teacher's effort in implementing character's values on culture is at the good level, shown by score: $71,66493 \%$.

The supporting factor is the implementation policy of curriculum 2013 for schooling. While the inhibiting factor in implementing character education in the MA is the lack of teacher knowledge of the values system of characters in Malay culture, lack of human resources (Headmaster and Teacher), Lack of Facilities and Infrastructure and low involvement of parents and community.

\section{Suggestions:-}

In relation to the above research findings it is necessary to present the following suggestions and recommendations:

1. To teachers of Islamic Education-Akidah Akhlak should further enhance the understanding of values and character education. Equally important is the ability of implementative in the process of learning in the class so that the value and character of Melayu Langkat culture can be developed.

2. To the principal should be able to further enhance the supervision and guidance counseling to teachers of Islamic Education-Akidah Akhlak in the application of character education.

3. Parents should build togetherness and cooperation with the school because the coaching of values and character can not be left only to the school. 


\section{References:-}

1. Depdiknas. (2004) of the RI Law. No. 20 of 2004 (UUSPN) and its Implementation Rules. Jakarta: Sinar Grafika.

2. Dep.Diknas. (2003). National Education System Act (UU SISDIKNAS) Jakarta: Sinar Grafika.

3. Dewantara, Ki Hajar. Karja Ki Hadjar Dewatara Part One: Education.

4. Djahiri, A.K. (1985). VCT and VCT Value-Effective Teaching Strategy in PVCT. Bandung: Faculty of Education Social Sciences IKIP-Bandung.

5. Djamari., (1999). Planting Insight and Essential Values in Teaching Geography for the Achievement of Educational Objectives, (Seminar on IMAHAGI in UPI, 23-09-1999.

6. Efendi, Tenas. (2005). Pantun Nasehat, Yogyakarta: Balai Kajian Melayu Working with Adicita Karya Nusa.7

7. Efendi, Tenas. (2010). Malay Thought Wisdom; Pekan Baru: Tenas Efendi Foundation.

8. Efendi, Tenas. (2011). Poetry and Malay Spirit; Pekanbaru: Tenas Efendi Foundation.

9. Interview with MAN 1 Tanjung Pura Hj Usmaidar, M.Pd, 5 October 2013.

10. Fraenkel, J. (1977). How to Teach Values: An Analytic Approach. Englewood Cliffs. NJ: Prentice-Hall.

11. Fraenkel, J. (1989). How to Teach Values: An Analytic Approach. Englewood Cliffs. NJ: Prentice-Hall. P.23.

12. Djahiri, A.K. (1996). Affective Tracing the World: Values and Morals Education. Bandung: LAB. Teaching PMP IKIP Bandung.hal. 6.

13. Joyce, D., Weil.M. (1972). Model of Teaching. Prentice Hall. Inc. New Jersey.

14. Kusnadi. (2000). Development of Learning Integration of Tauhid Values in Geography Learning at SMUN 19 Kotamadya Bandung. (Thesis S-2 PPS UPI Bandung).

15. Koesoema, Doni. (2011). Character Education: Strategy to Educate Children in the Global Age, (Jakarta: Kompas Gramedia, 2011).

16. Samani, Hariyanto. (2011). Concept and Model Character Education, Jakarta: PT. Youth Rosdakarya, p. 43.

17. Zubaedi. (2011). Character Education Design: Conception and Application in Educational Institution, Jakarta: Kencana Prenada Media Group, p. 26.

18. Koesoema, Doni. (2011). Character Education: The Strategy to Educate Children in the Global Age, London: Kompas Gramedia, p. 41. 